\title{
田路澄代 学位論文審査要旨
}

\author{
主 査 渡 邊 達 生 \\ 副主査福 本 宗 嗣 \\ 同宮川征男
}

\section{主論文}

Effects of long-term estrogen treatment on micturition behavior and the sensory neurons of the urinary bladder in old female rats

(老齢此ラットにおけるエストロゲン補充療法の排尿行動および膀胱感覚神経 に及ぼす影響）

(著者：田路澄代、渡邊健志、宮川征男)

平成 20 年 Urologia Internationalis 掲載予定 


\section{学 位 論 文 要 旨}

\section{Effects of long-term estrogen treatment on micturition behavior and the sensory neurons of the urinary bladder in old female rats （老齢雌ラットにおけるエストロゲン補充療法の排尿行動および膀胱覚 神経に及ぼす影響）}

女性尿失禁の多くは腹圧性尿失禁であり、6.4\%〜 $35.0 \%$ の女性に認められる との報告がある。また、加齢とともに切迫性尿失禁が増加して生活の質がさら に低下することが知られている。腹圧性尿失禁と切迫性尿失禁をあわせもつ混 合性尿失禁に対しては、エストロゲン療法が治療の 1 つとされているが、逆に 尿失禁を悪化させるという報告もあり、エストロゲンの有効性に関しては見解 が一致していない。したがって、この点に関して基礎的検討が続いているが、 尿失禁と深い因果関係にある求心路神経に及ぼすエストロゲン療法の影響は検 討が全くなされていない。今回、老齢此ラットに対してエストロゲン補充療法 を行い、排尿行動及び求心路神経の変化を調べた。

\section{方 法}

13 ケ月齢の老齢Wistar 䧳ラット 12 匹をそれぞれ無作為にコントロール群と エストロゲン補充群の 2 群に分け、コントロール群（n=6）にはセサミオイルを $0.2 \mathrm{ml}$ 、エストロゲン補充群（n=6）には $\beta$-estradiol $20 \mu \mathrm{g} / \mathrm{kg}$ を 1 日 1 回、12 週間連日皮下投与した。注射終了後メタボリックケージ内で多尿状態での 24 時 間の排尿行動の記録を行った。具体的には、飲み水を 5\%スクロース水に替え排 尿行動を観察した。排尿行動記録後、2.5 ml の採血を行い、血清エストラジオ ール濃度を測定した。さらに、後根神経節を摘出し $\mathrm{P} \mathrm{X}_{3}$ 、calcitonin gene-related peptide (CGRP)、substance P に対する免疫染色を行い、それぞ れの陽性神経細胞の比率を検討した。

\section{結 果}

エストロゲン補充群ではコントロール群と比較し体重増加は認めなかったが、 膀胱重量、血清エストラジオール濃度の著明な増加を認めた。

排尿行動に関しては、最大排尿容量に加え、平均排尿容量もエストロゲン補 充群で有意に増加し、排尿回数の有意な減少を認めた。

後根神経節の免疫染色では P $2 X_{3} 、 C G R P 、$ substance P のいずれにおいてもエ 
ストロゲン補充療法によって免疫活性細胞陽性率に有意な变化を認めなかった。

\section{考 察}

今回の研究では、エストロゲン補充療法により多尿状態で最大排尿容量のみ ならず平均排尿容量も増加し、排尿回数は減少した。すなわち、膀胱容量が増 大した。

卵巣を摘除すると膀胱粘膜と平滑筋の血流が低下して膀胱が萎縮する。加齢 などによる慢性虚血により排尿筋に除神経が生じ、排尿筋不安定が生じる。さ らにはエストロゲン補充療法により血管新生を認めたとする報告がある。した がって、今回観察されたエストロゲン補充療法による膀胱容量の増大は、血流 増加によるものと考えられる。一方、 $\mathrm{P}_{2} \mathrm{X}_{3}$ 欠損ラットでは正常ラットより最大 排尿容量は多く、排尿回数は少なかったと報告されている。したがって、エス トロゲンにより膀胱の $\mathrm{P}_{2} \mathrm{X}_{3}$ などの求心路の興奮が抑制された可能性が高い。そ こで、後根神経節での P $2 X_{3} 、$ CGRP、substance P の変化を免疫染色で検討したが、 いずれもエストロゲン補充療法による変化は認められなかった。

この結果をもってただちにエストロゲン補充療法は排尿神経回路求心路に及 ぼす影響がないと結論できないが、求心路に関してはいまだ不明なことも多く、 今後更なる研究が必要と思われる。

\section{結 論}

13 ケ月齢の老齢Wister 雌ラットにおいてエストロゲン補充療法は、多尿刺激 下で平均および最大排尿容量を増加させ、排尿回数を減少させた。この現象に、 求心路の $\mathrm{P} 2 \mathrm{X}_{3} 、 \mathrm{CGRP} 、$ substance P の関与はないものと推察される。 